\title{
CHARACTERIZATION AND CELULAR PROLIFERATION OF OVARIAN STRUCTURES OF EWES BY THE TECHNIQUE OF AGNOR: OVARIAN MORFOMETRY AND CORRELATIONS
}

BIOENG

\author{
M. G. M. Chacur ${ }^{1 *}$, T. A. H. Arrebola ${ }^{1}$; D. B. Ibrahim ${ }^{1}$; O. C. Sanches ${ }^{1}$; \\ L. R. A. Gabriel Filho ${ }^{2}$; C. P. Cremasco ${ }^{2}$; F. F. Putti ${ }^{3}$
}

${ }^{1}$ UNOESTE - Univ do Oeste Paulista, Campus II, Laboratório de Reprodução Animal, Presidente Prudente, SP, Brasil

${ }^{2}$ UNESP - Univ Estadual Paulista, Campus de Tupã, Laboratório de Matemática Aplicada e Computacional, SP, Brasil

${ }^{3}$ UNIFENAS - Univ José do Rosário Vellano, Campus de Alfenas, MG, Brasil

Article history: Received 30 July 2015; Received in revised form 21 August 2015; Accepted 25 August 2015; Available online 30 September 2015.

\section{ABSTRACT}

The AgNOR staining technique for nucleolar organizer regions (NORs) is characterized by marking proteins related to ribossomal ribonucleic acid evaluating celular proliferation. The objective was to study the ovarian morphometry and the value of AgNOR thecnique application to evaluate the proliferation of healthy cels from ovarian structures in crossbred ewe. 102 pairs of ovaries were collected and from the largest follicle of each ovary was measured its diameter. From the largest corpus luteum (CL) was measured the diameter and width, classifying the CL in: included, protruberant, massive and cavity, followed by AgNOR staining. The significance level was 5\%. It had difference $(\mathrm{p}<0.05)$ for the diameter of the largest follicle between right (RO): $4.2 \pm 2,3 \mathrm{~mm}$ and left (LO): $3.6 \pm 2,2 \mathrm{~mm}$ sides. There was a correlation $(\mathrm{p}<0.01)$ between the NORs of internal theca (IT) and external theca (ET): RO (0.46) and LO (0.61); NORs of granulosa and IT: RO (0.54) and LO (0.59); and NORs of granulosa and ET: RO (0.34) and LO (0.38). Was conclude that the NORs quantification was appropriate to study the determination of the potential for ovarian structures proliferation, which was similar for right and left sides.

Keywords: ovis aries, ovarian anatomy, celular proliferation, argyrophilic protein.

\section{RESUMO}

A técnica de coloração AgNOR para regiões organizadoras de nucléolos (NORs) é caracterizada por marcar proteínas ligadas ao ácido ribonucléico ribossômico, avaliando a proliferação celular. O objetivo do trabalho foi estudar a morfometria ovariana e a validade da técnica AgNOR na proliferação de células saudáveis das estruturas ovarianas em ovelhas mestiças. Foram colhidos 102 pares de ovários e mensurou-se o diâmetro do maior folículo de cada ovário. Do maior corpo lúteo (CL), o diâmetro e a largura foram mensurados, classificando-os em: incluso, protruso, maciço e cavitário, seguidos por coloração AgNOR. O nível de significância foi de 5\% (R Statistical System). Houve diferença $(\mathrm{p}<0,05)$ para o diâmetro do maior folículo entre os lados direito (OD): $4,2 \pm 2,3 \mathrm{~mm}$ e esquerdo (OE): $3,6 \pm 2,2 \mathrm{~mm}$. Houve correlação $(\mathrm{p}<0,01)$ entre as NORs da teca interna (TI) e externa (TE): OD $(0,46)$ e OE $(0,61)$; NORs da granulosa e TI: OD $(0,54)$ e OE $(0,59)$; e entre NORs da granulosa e TE: OD $(0,34)$ e $\mathrm{OE}(0,38)$. Conclui-se que a quantificação das NORs foi

*chacur@unoeste.br 
apropriada para o estudo da determinação do potencial de proliferação das estruturas ovarianas, a qual foi similar para os lados direito e esquerdo.

Palavras-chave: ovis aries, anatomia ovariana, proliferação celular, proteína argirofílica.

\section{INTRODUCION}

According to the Anuário da Pecuária Brasileira 2014, in 2008 there was a flock of 453,261 thousand head of sheep in the state of São Paulo in Brazil inside 19 million.

This expansion promotes the search of optimization techniques for manipulating the estrus cycle and for the use in biotechniques, being necessary to know, in addition to reproductive endocrinology, anatomy and histology of the ovaries (TRALDI, 2006).

The applied study of ovarian morphology is directly related to the interpretation of the estrous cycle and use of biotechnologies of reproduction in sheep industry, which currently occupies a place of importance in livestock farms of zootechnical interest (SIMPLICIO et al., 2002; BOUCHE et al., 2011).

The female genital organs responsible for the growth and maturation of oocytes are the ovaries. In sheep, the gonads have almond shape with approximately $1.5 \mathrm{~cm}$ in length and weight around 3 to $4 \mathrm{~g}$ (SISSON, 1986), consist of germinal epithelium squamous or simple cuboid surrounding the cortex (HAFEZ \& HAFEZ, 2004).

The structure and cellular proliferation of developing follicles present in the cortex, is different for each stage and can range in size from $40 \mu \mathrm{m}$ to $5.5 \mathrm{~mm}$ in diameter (HEMAMALINI et al., 2003; URIBE-VELASQUEZ et al., 2008).

The cells of the corpus luteum (CL) stem cells of the theca interna and granulosa membrane with hypertrophy and hyperplasia, being called small and large luteal cells, respectively (FITZ et al., 1982).

The ability of follicle cell proliferation was studied in rats by Silva et al. (2003) using the AgNOR technique, being the same color employed in the assessment of cell proliferation in tumors (LINDNER, 1993 \& TRERÈ, 2000). Said AgNOR technique consistis in stain proteins linked to the ribosomal ribonucleic acid (rRNA) with silver (Ag), to obtain a precipitate of lumps nucleolus called nucleolar organizer regions (NORs) (CROCKER et al., 1989). These proteins are synthesized during the interphase of the cell cycle and have affinity for silver forming the NORs, which can be observed and counted under an optical microscope (MURRAY, 2004). The technique assesses the NORs of chromosomes assets and show the cellular proliferative activity (CRESTA \& ALVES, 2007).

Research on the increase in reproduction efficiency is optimizing and improving techniques. Letelier et al., 2011 researched on the induction of estrus with progestogens or prostaglandine, melatonine and norgestomet (USLU et al., 2012), prostaglandines (FIERRO et al., 2013), progesterone (VILARIÑO et al., 2013), bisphenol A or diethylstilbestrol (RIVERA et al., 2011) and lectin (GRAZUL-BILSKA et al., 2013).

It should also be enhanced that factors may make difficult pregnancy in lambs, such as nutrition (BLAIR et al., 2011), roughage feeding during heat (HASHEM \& SALLAM, 2012) and photoperiod (LAGARAINE et al., 2011).

It is worth noting that given the paucity of information gathered in the literature review, related to the use of AgNOR technique with the purpose of studying the cellular proliferation of ovarian structures in healthy animal species, among them the sheep, aimed to study the ovarian morphology and validity of using the AgNOR technique in healthy cell proliferation of ovarian structures in crossbred sheep ovarian. 


\section{MATERIAL AND METHODS}

Sheep ovaries were collected from slaughterhouse belonging to the municipality of Promissão-SP (altitude: 426m, latitude: $21^{\circ} 32^{\prime} 12^{\prime \prime S}$, longitude: $49^{\circ} 51^{\prime} 29^{\prime \prime} \mathrm{W}$ ), immediately after slaughter and evisceration of animals. Altogether was collected 102 pairs of ovaries belonging to crossbred sheep (wool breeds $\mathrm{x}$ wooless breeds), between 6 and 12 months of age, not pregnant, in the months from March to May (late summer / autumn) 2010.

The gonads were identified in right ovary (RO) and left ovary (LO) in individual bags for each pair of ovaries, stored and transported in saline at $37^{\circ} \mathrm{C}$, during 3 hours, for laboratories of Animal Reproduction and Veterinary Pathology of UNOESTE. Was performed morphometric analysis with a caliper, in order to check the length $(\mathrm{mm})$ in the major axis; the width $(\mathrm{mm})$ between the shaft ovarian pedicle and the opposite end; and the height $(\mathrm{mm})$, in the axis of 90 degrees in relation to the width.

By immersing the ovaries in a graduated cylinder containing saline solution was obtained the volume $(\mathrm{ml})$ of the gonads and with the aid of a digital scale has measured the weight $(\mathrm{g})$ of the ovaries.

The classification of follicles evaluated was performed according to Figueiredo et al. (2008), wherein tertiary follicles have a diameter equal or larger than $119 \mu \mathrm{m}$.

Before the longitudinal cut, the two larger follicles were identified macroscopically for each ovary and was measured as its diameter (mm). After slitting, the corpus luteum (CL) was evaluated as its diameter ( $\mathrm{mm})$ and width $(\mathrm{mm})$, being the area defined by calculating from the area of the ellipse determined by the relation:

$$
\text { Area }=\pi \cdot D \cdot L / 4
$$

where: $D$ is the diameter and $L$ the width of CL.
The CL were also classified according to the types: included, protruberant, massive and cavity (CHACUR et al., 2006).

AgNOR staining technique as proposed by Sanches (2010), adapted from Ploton et al. (1986): Using the solution named Davidson (Fixer Davidson A.F.A.: formol $20 \mathrm{~mL}$, alcohol $95 \% 30 \mathrm{~mL}$, acetic acid $10 \mathrm{~mL}$, distilled water $30 \mathrm{~mL}$ ), small samples of sheep ovarian tissue (ovarian lengthwise) were fixed, with approximately $0.5 \mathrm{~mm}$ wide, by 24 to 48 hours. After this period they were washed in running water for 1 hour and transferred to a solution of alcohol $70 \%$ and then dehydrated in ascending alcohol series (80\%, $96 \%$ and $100 \%$ alcohol), remaining 40 minutes on each "alcohol". Diaphanization (or lightening) was performed using four stages of 40 minutes, the first being the alcohol + xylene (1:1) and the other three with only xylene. Paraffin embedding was performed by inserting the tissue sample in paraffin with melting point $56^{\circ} \mathrm{C}-60^{\circ} \mathrm{C}$ twice for subsequent paraffin embedding and mounting blocks. The samples in paraffin blocks were cut into $5 \mathrm{~mm}$ thick, using a rotary microtome (Microtome Cutter Block, mod. 820, American Optical N45387, USA). Subsequently, they were deparaffinized in xylene for 5 minutes (three times), passing hydrated slowly in absolute alcohol (100\%) three times and washed with tap water for 5 minutes. The cuts in the blade, were incubated under light in a humid chamber for 40 minutes at $60^{\circ} \mathrm{C}$ in a solution containing silver nitrate, obtained using $1 \mathrm{~g}$ of colorless gelatin, 0.5 $\mathrm{ml}$ of formic acid and $50 \mathrm{~mL}$ of deionized water (solution $\mathrm{A}$ ) and $12.5 \mathrm{~g}$ of silver nitrate and $25 \mathrm{~mL}$ of deionized water (solution B), being a part of solution A to two parts of solution B.

The samples were removed from the dye solution when presented brownish in color and washed in warm deionized water at $45^{\circ} \mathrm{C}$ in order to remove the precipitate formed by gelatin. After this, the blades 
have passed into solution of sodium thiosulfate $5 \%$ for 5 minutes to remove reduced silver deposited on the whole cells. Samples were dried (alcohol 96\% and $100 \%$ - 3 times, slowly; xylene - 3 times slowly), Van Gieson placed in (or "green light") for 3 minutes, to complete assembly of the blades and coverslip with synthetic resin (Entellan ${ }^{\circledR}$, Merck KGaA, Darmstadt, Alemanha).

The counting of nucleolar organizer regions (NORs) was performed taking lumps of nucleoli, that could be counted according to the number of dots in the nucleus of each cell type present in the ovary, these being: follicle (external theca, internal theca and granulosa); CL; and corpus albicans, by means of optical microscopy in magnitude (1000X).

The pattern of NOR count was performed considering 10 cells / field of each cell type, repeating in 10 microscopic fields, totaling a count of 100 cells of each of the cell types as Sanches (2010) adapted from Löhr et al. (1997).

Data analysis of the ovarian morphology was obtained from the results of the averages that were submitted, for groups with normal distribution, to analysis of variance by $\mathrm{F}$ test, according Cremasco et al. (2009), for paired

\section{RESULTS AND DISCUSSION}

In geographical location close to the present study with crossbred ewes, Sasa et al. (2001) in the region located at $21^{\circ} 59^{\prime} \mathrm{S}$, $47^{\circ} 26^{\prime} \mathrm{O}$ (Pirassununga, SP), reported that females Santa Ines (wooless breed) had little influence of photoperiod, in contrast, females of Romney Marsh and Suffolk (wool breeds) had anestrus observed from August. The same result was obtained in the previous close geographic region by Rodrigues et al. (2007), who concluded that the location interferes with the response to light stimulus, whereas Romney Marsh sheep and Sulfolk, breeds from high latitudes, showed maximum reproductive activity during the autumn and winter. observations as completely randomized design, statistical analysis similar to that performed in animal science area in Gabriel Filho et al. (2011), Chacur et al. (2012, 2013, 2014) and Castilho et al. (2013, 2015).

The mathematical statistical model used in this paper is given by:

$$
x_{i j}=m+t_{i}+e_{i j}
$$

where in: $x_{i j}=$ observed on the side portion $i$ and repetition $j ; m=$ overall average; $t_{i}=$ side effects of $i ; e_{i j}=$ effect of chance.

For groups with non-normal distribution, we performed analysis of variance using the Friedman test. In all tests, the significance level was $5 \%$, and used the computer program R Statistical System (IHAKA \& GENTLEMAN, 1996) to perform the statistical analyzes.

For some pairs of measurements of interest was calculated correlation coefficient using the Student $t$ test. For the number of $\mathrm{CL}$ was applied the chi-square $\left(\chi^{2}\right)$.

Was used the Spearman correlation because the ranks of data classification for AgNOR staining technique.

Data obtained by Sousa et al. (2008), with crossbred ewes (Sulfolk $x$ Ile de France) at latitude $22^{\circ} 53^{\prime} \mathrm{S}$ and longitude 46 $29^{\prime}$ O (Botucatu, SP), confirmed reproductive activity throughout the year.

The volume of the right ovary (RO) revealed a coefficient of variation $(\mathrm{CV})$ of $55 \%$ and the volume of the left ovary (LO) of $56 \%$. The ovarian weight showed CV between $54 \%$ and $57 \%$, these values being higher than those obtained for the CV's length, width and height, respectively $19 \%$, $26 \%$ and $25 \%$ for RO, and $20 \%, 31 \%$ and $27 \%$ for LO (Table 1 ).

In ovarian morphometry no significant differences ( $p>0.05)$ according to Table 1 , with results of $12.7 \pm 2.5 \mathrm{~mm}$ (RO) and $12.4 \pm 2.5 \mathrm{~mm}$ (LO) in length, 
and $0,87 \pm 0.47 \mathrm{~g}(\mathrm{OD})$ and $0.79 \pm 0.45 \mathrm{~g}$ (OE), similar to values obtained by Tasende et al. (2002), in Uruguay in Corriedale in September with ovarian lengths between $10.2 \pm 0.6 \mathrm{~mm}$ and $14.9 \pm$ $0.3 \mathrm{~mm}$ and weight of the ovaries of $0.70 \pm$ $0.03 \mathrm{~g}$. It is noteworthy that the Corriedale ewes were in anestrus (September) and, probably, length and weight of ovaries were influenced in the month above. Thus the similarity can be observed between these two parameters in this study with crossbred ewes (wool breeds $\times$ wooless breeds) with cyclic ovarian activity.

Table 1. Means and results of analysis of variance of length, width, height, weight and volume of 102 pairs of crossbred sheep ovaries collected from slaughterhouse.

\begin{tabular}{|c|c|c|c|c|c|c|c|c|c|c|}
\hline \multicolumn{11}{|c|}{ Ovaries } \\
\hline & \multicolumn{2}{|c|}{ Length (mm) } & \multicolumn{2}{|c|}{ Width (mm) } & \multicolumn{2}{|c|}{ Height(mm) } & \multicolumn{2}{|c|}{ Weight $(\mathrm{g})$} & \multicolumn{2}{|c|}{ Volume (mL) } \\
\hline & $\mathrm{RO}$ & $\mathrm{LO}$ & RO & LO & RO & LO & $\mathrm{RO}$ & LO & $\mathrm{RO}$ & LO \\
\hline Mean & 12.7 & 12.4 & 9.2 & 8.8 & 10.7 & 10.3 & 0.87 & 0.79 & 0.85 & 0.78 \\
\hline SD & 2.5 & 2.5 & 2.3 & 2.7 & 2.6 & 2.8 & 0.47 & 0.45 & 0.46 & 0.44 \\
\hline $\mathrm{CV}(\%)$ & 19 & 20 & 26 & 31 & 25 & 27 & 54 & 57 & 55 & 56 \\
\hline$P$ value & \multicolumn{2}{|c|}{$0.919^{\mathrm{NS}}$} & \multicolumn{2}{|c|}{$0.302^{\mathrm{NS}}$} & \multicolumn{2}{|c|}{$0.206^{\mathrm{NS}}$} & \multicolumn{2}{|c|}{$0.225^{\mathrm{NS}}$} & \multicolumn{2}{|c|}{$0.473^{\mathrm{NS}}$} \\
\hline
\end{tabular}

As for ovarian structures, were measured only two follicles that had bigger diameter in each ovary. For the largest follicle was no significant difference ( $\mathrm{p}$ $<0.05)$ between the right $(4.2 \pm 2.3 \mathrm{~mm})$ and left $(3.6 \pm 2.2 \mathrm{~mm})$ sides and for the second largest follicle was obtained difference $(\mathrm{p}<0.05)$ between the right and left sides, being $2.3 \pm 0.9 \mathrm{~mm}$ and $1.5 \pm 1.1$ $\mathrm{mm}$ respectively (Table 2 ). Values lower than those reported by Uribe-Velasquez et al. (2008) with an average of $5.5 \mathrm{~mm}$ in Bergamasca. This difference may be related to different genetic origin of animals.

Table 2. Means and results of analysis of variance of ovarian structures (follicles and CL) of 102 pairs of crossbred sheep ovaries collected from slaughterhouse.

\begin{tabular}{lcccccccc}
\hline \multicolumn{10}{c}{ Ovaries } \\
\hline & \multicolumn{10}{c}{$>$ Fol. $(\mathrm{mm})$} & \multicolumn{2}{c}{$2^{\circ}>$ Fol. $(\mathrm{mm})$} & \multicolumn{2}{c}{ Diameter CL $(\mathrm{mm})$} & \multicolumn{2}{c}{ Width CL $(\mathrm{mm})$} \\
\hline Mean & RO & LO & RO & LO & RO & LO & RO & LO \\
SD & 2.2 & 3.6 & 2.3 & 1.5 & 6,6 & 5.7 & 6.9 & 5.4 \\
CV (\%) & 54 & 61 & 42 & 73 & 45 & 55 & 47 & 53 \\
p value & \multicolumn{2}{c}{$0.024^{*}$} & $<0.001 *$ & 1.1 & 2.9 & 3.1 & 3.2 & 2.9 \\
\hline
\end{tabular}

SD: Standard Deviation; CV: Coefficient of variation; *significant at the 5\%; ${ }^{\mathrm{NS}}$ not significant; RO: right ovary; LO: left ovary; >Fol.: diameter of the largest follicle; $2^{\circ}>$ Fol.: the second largest follicle diameter.

It was observed that from 204 ovaries, $42.65 \%$ (87) of these had CL and these, $50.57 \%$ (44) were present in the right and $49.43 \%$ (43) at the left side. There was no difference $(p>0.05)$ between the right and left sides for the number of CL.

Regarding CL present in the right and left ovaries, corroborates Moakhar et al. (2010), showing homogeneity in luteal cyclic ovarian activity. 
Regarding the morphology of the $\mathrm{CL}$, there was a predominance of massive $(75.86 \%)$ and included $(59.77 \%)$ on the types cavity $(24.14 \%)$ and protruberant
$(40.23 \%)$ in 87 ovaries with presence of the structure. For the sheep, according to the literature, there is no information regarding the classification of CL.

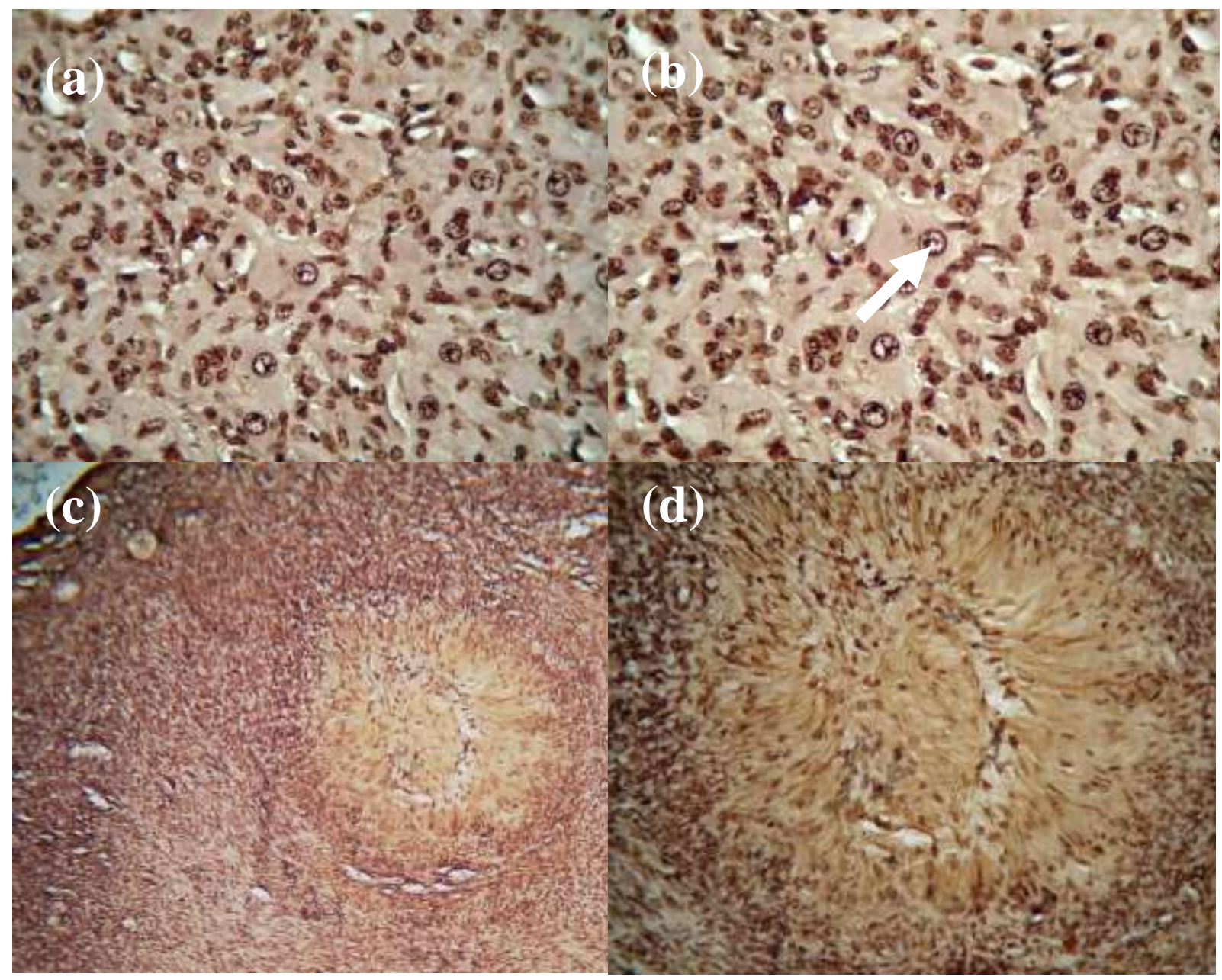

Figure 1. Photomicrograph cutting sheep ovary, where NORs observed (arrow). Corpus luteum in magnitude (400X) (a) and (1000X) with cells having large NORs in the center of the core and smaller in the periphery (b) Corpus albicans in magnitude (100X) (c) and (400X) (d).

For the correlation between the mean of NORs in ovarian structures to the right and left sides, there was no significant difference ( $p>0.05$, Table 3$)$.

Table 3. Correlations between RO and LO for the average number of NORs of ovarian structures of crossbred ewes: corpus luteum, corpus albicans, granulosa, internal theca and external theca.

\begin{tabular}{lccc}
\hline \multirow{2}{*}{ Ovarian Structures } & \multicolumn{2}{c}{ Mean (NORs) } & \multirow{2}{*}{ P value } \\
\cline { 2 - 3 } & RO & LO & \\
\hline Corpus Luteum & 5.00 & 4.00 & $0.782^{\mathrm{NS}}$ \\
Corpus Albicans & 3.88 & 4.00 & $0.815^{\mathrm{NS}}$ \\
Granulosa & 7.00 & 7.00 & $0.691^{\mathrm{NS}}$ \\
Internal Theca & 6.00 & 6.00 & $0.307^{\mathrm{NS}}$ \\
External Theca & 5.00 & 5.00 & $0.160^{\mathrm{NS}}$ \\
\hline
\end{tabular}


This means that the structures proliferate similarly independent of the anatomical part. In this study, was assessed the largest follicles in each ovary (being all tertiary) and got up, mostly small and numerous NORs, especially for granulosa cells with an average of 7 NORs. Data from Silva et al. (2003) with rats, although they have not worked with tertiary follicles showed that the follicles with two to three cell layers had few major NORs and follicles with more than 5 layers of cells had many small dots to count the cells
NORs of granulosa from secondary follicles without the formation of the antrum.

With these observations can be explained using the AgNOR staining technique to assess cell proliferation in healthy follicular cells and not only in tumor processes as shown Pich et al. (2000), in a review of literature on the reproductive and respiratory systems of humans, which reports that the greater the number of NORs, higher will be the proliferative activity of cells.

Table 4 . Correlations of variables to count the NORs present in 162 ovaries, 81 on the right (RO) and 81 on the left (LO) of crossbred ewes collected at slaughterhouse.

\begin{tabular}{lcccc}
\hline \multirow{2}{*}{\multicolumn{1}{c}{ Parameters }} & \multicolumn{2}{c}{ RO } & \multicolumn{2}{c}{ LO } \\
\cline { 2 - 5 } & Correlations & p value & Correlations & p value \\
\hline I.T. NORs and E.T NORs & $0.468^{* *}$ & 0.000 & $0.611^{* *}$ & 0.000 \\
CL NORs and Granulosa NORs & $-0.109^{\mathrm{NS}}$ & 0.462 & $-0.015^{\mathrm{NS}}$ & 0.929 \\
CL NORs and I.T. NORs & $-0.095^{\mathrm{NS}}$ & 0.539 & $-0.012^{\mathrm{NS}}$ & 0.944 \\
CL NORs and NORs E.T. & $-0.088^{\mathrm{NS}}$ & 0.568 & $0.020^{\mathrm{NS}}$ & 0.912 \\
Granulosa NORs and I.T. NORs & $0.545^{* *}$ & 0.000 & $0.590^{* *}$ & 0.000 \\
Granulosa NORs and E.T. NORs & $0.341^{* *}$ & 0.002 & $0.389^{* *}$ & 0.001 \\
\hline *significant at 1\%; ${ }^{\text {NS }}$ not significant; NORs: nucleolar organizer regions; CL: corpus luteum; I.T.: internal \\
\multicolumn{2}{c}{ theca; E.T.: external theca. }
\end{tabular}

There were positive correlations $(\mathrm{p}<0.01)$ between NORs of internal theca (IT) and NORs of external theca (ET) of 0.468 to $\mathrm{RO}$ and 0.611 for LO. This is due probably to the fact of theca cells are stimulated to cell differentiation and proliferation by several factors, including the luteinizing hormone (LH), inducing luteinization/differentiation of theca cells, and IGF (growth factor insulinlike) inducing cell proliferation, as review of the literature considering the sheep (YOUNG \& MCNEILLY, 2010).

The photomicrographs for the tertiary follicle and their structures can show the NORs (Figure 2). 

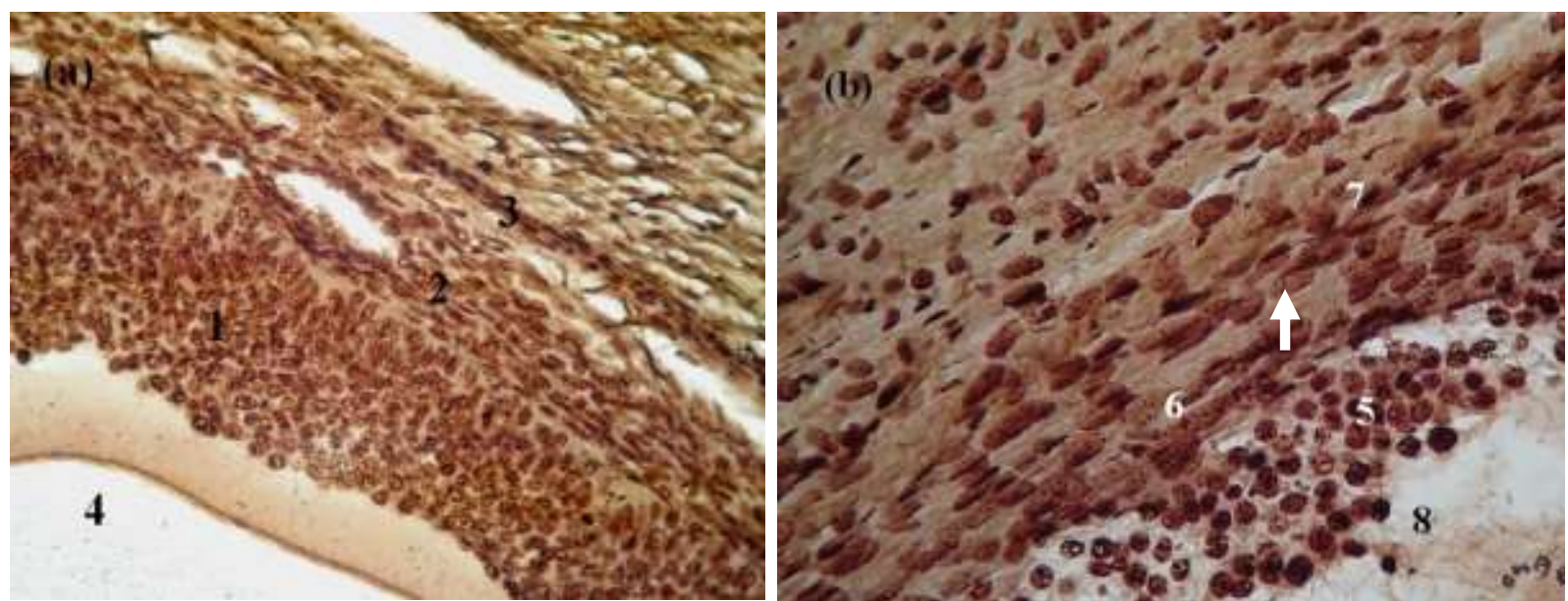

Figure 2. Photomicrograph cutting sheep ovary, which shows small NORs (arrow). Antral follicles in magnitude (400X) where: 1-granulosa, 2-internal theca, 3-external theca, 4-den (a); Tertiary follicle in magnitude (1000X) where: 5-granulosa, 6-internal theca, 7-external theca, 8-den (b).

Also was obtained a positive correlation $(\mathrm{p}<0.01)$ between NORs of granulosa and NORs of IT of 0.545 for RO and of 0.590 for LO; and between NORs of granulosa and NORs of ET of 0.341 and 0.389 for RO and LO respectively. This result may be related to the fact that granulosa cells are also in differentiation and activity (both for production of antral fluid, as for differentiation into luteal cells) and technical brand NORs cells during protein synthesis and increase in volume (UNDERWOOD, 1995). Thus, the higher the rate of cell proliferation, the greater the number of small NORs (ribosomal RNA),

\section{CONCLUSIONS}

This study demonstrates that the AgNOR staining technique in conjunction with ovarian morphology is a good parameter to assess the proliferative potential of the cells of the corpus luteum, granulosa, internal theca and external theca.

The quantification of NORs was appropriate to determine the proliferation and the values obtained for the NORs in this study mean that the granulosa cells have high proliferation rate for the production of hormones and subsequent formation of CL and theca cells (HASTIE \& HARESIGN, 2009).

There was no correlation between NORs of CL and NORs of the cell types of the follicle (granulosa, IT and ET), because they are cells from different structures.

Because of the AgNOR technique, related to the study of cell proliferation in ovarian structures of healthy cells in domestic animals and especially in sheep, not to bring information in the literature.

potential of cells from healthy ovarian structures evaluated, which was similar to the right and left sides.

The AgNOR staining technique was effective to see that there is a positive correlation to the proliferative potential between internal theca and theca externa cells and between granulose and between granulosa cells with both tecas. 


\section{REFERENCES}

ANUÁRIO DA PECUÁRIA BRASILEIRA - Anualpec. São Paulo: AgraFNP, 2014. p.273.

BLAIR, H. T.; VAN DER LINDEN, D. S.; JENKINSON, C. M. C.; MORRIS, S. T.; MACKENZIE, D. D. S.; PETERSON, S. W.; FIRTH, E. C.; KENYON, P. R. Do ewe size and nutrition during pregnancy affect foetus and foetal organ weight in twins? Livestock Science, Amesterdan, v. 142, n.1-3, p. 99-107, 2011.

BOUCHE, R.; DERKIMBA, A.; CASABIANCA, F.. New trends for innovation in the Mediterranean animal production. Springer Science \& Business Media, 2011.

CASIDA, L.E.; WOODY, C.O.; POPE, A.L. Inequality in functin of the right and left ovaries and uterine horns of the ewe. Journal of Animal Science, Champaign, v. 25, n. 4, p.1169-1171, 1966.

CASTILHO, C.; ALMEIDA, M. F.; COSTA, M. Z.; CESARE, A. G.; GABRIEL FILHO, L. R. A. Protocolos de indução e sincronização do estro em ovelhas. Ciência Animal Brasileira, Goiânia, v. 14, n. 1, p. 91-97, 2013.

CASTILHO, C.; ALMEIDA, M. F.; GIOMETTI, I. C.; COSTA, M. Z.; GABRIEL FILHO, L. R. A.; CESARE, A. G. Use of estradiol benzoate to induce ovulation in a short-term protocol for fixed-time AI in sheep. Semina Ciências Agrárias, Londrina, v. 36, n. 3, p. 14191424, 2015.

CHACUR, M. G. M.; VALENTIM, N. C.; MARTINEZ, A. I. S. ; TOSTES, R. A.; KRONKA, S. N. Morfometria de ovários de fêmeas zebu Bos taurus indicus coletados em matadouro. Acta Scientiae Veterinariae, Porto Alegre, v. 34, n. 1, p. 65-70, 2006.
CHACUR, M. G. M.; MIZUSAKI, K. T.; SANTOS, F. H.; CESARE, A. G.; GABRIEL FILHO, L. R. A.; OBA, E.; RAMOS, A. A. Influência da estação do ano nas características do sêmen e na concentração de hormônios em touros Nelore e Simental. Arquivo Brasileiro de Medicina Veterinária e Zootecnia, Belo Horizonte, v. 64, n. 3, p. 540-546, 2012.

CHACUR, M. G. M.; MIZUSAKI, K. T.; GABRIEL FILHO, L. R. A., OBA, E.; RAMOS, A. A. Seasonal Effects on Semen and Testosterone in Zebu and Taurine Bulls. Acta Scientiae Veterinariae, Porto Alegre, v. 41, p. 1-4, 2013.

CHACUR, M. G. M.; MARTINS, E. A. F.; SILVA, A. A.; GUABERTO, L. M.; GABRIEL FILHO, L. R. A.; SANCHES, O. C.; OBA, E. Morfometria corpórea, características do sêmen, proteínas seminais e testosterona em cervos Cervus unicolor, em cativeiro. Arquivo Brasileiro de Medicina Veterinária e Zootecnia, Belo Horizonte, v.66, n.5, p.1392-1400, 2014.

CREMASCO, C. P., GABRIEL FILHO, L. R. A., GABRIEL, L. R. A. Bioestatística e suas Aplicações. Adamantina: Editora Espaço Cultural do Brasil, 2009, v.1, p.198.

CRESTA, F. B.; ALVES, M. R. Avaliação da cinética do epitélio corneano com marcadores de proliferação celular. Arquivos Brasileiros de Oftalmologia, São Paulo, v. 70, n. 6, p. 953-960, 2007.

CROCKER, J.; BOLDY, D. A. R.; EGAN, M. J. How should we count AgNORs? Proposals for a standardized approach. The Journal of Pathology, Londres, v. 158, p. 185-188, 1989.

FIERRO, S.; GIL， J.; VIÑOLES, C.; MUZANTE, J. O. The use of prostaglandins in controlling estrous cycle 
of the ewe: A review. Theriogenology, Milão, v. 79, n. 3, p. 399-408, 2013.

FIGUEIREDO, J. R.; RODRIGUES, A. P. R.; AMORIM, C. A.; SILVA J. R. V. Manipulação dos Oócitos Inclusos em Folículos Ovarianos Pré-antrais. In: GONÇALVES, P. B. D.; FIGUEIREDO, J. R.; FREITAS, V. J. F. Biotécnicas Aplicadas à Reprodução Animal, 2.ed. São Paulo: ROCA, 2008. p.303-328.

FITZ, T. A.; MAYAN, M. H.; SAWYER, H. R. NISWENDER, G. D. Characterization of Two Steroidogenic Cell Types in the Ovine Corpus Luteum. Biology of Reproduction, Madison, n. 27, n. 3, p. 703-711, 1982.

GABRIEL FILHO, L. R. A.; CREMASCO, C. P.; PUTTI, F. F.; CHACUR, M. G. M. Application of fuzzy logic for the evaluation of livestock slaughtering. Engenharia Agrícola, Jaboticabal, v. 31, n. 4, p. 813-825, 2011.

GRAZUL-BILSKA, A. T.; BOROWICZ, P. P.; REYNOLDS, L. P.; REDMER, D. A. Vascular perfusion with fluorescent labeled lectin to study ovarian functions. Acta Histochemica, Amsterdam, v. 115, n. 8, p. 893-898, 2013.

HAFEZ, B.; HAFEZ, E. S. E. Anatomia da Reprodução Feminina. In: HAFEZ, E. S. E.; HAFEZ, B. Reprodução Animal, 7.ed. São Paulo: Manole, 2004. p.13-30.

HASHEM, N. M.; SALLAM, S. M. A. Sexual and ovarian activity of crossbred ewes fed different types of roughage during seasonal anestrus. Small Ruminant Research, Amsterdam, v.107, n. 2, p.136140, 2012.

HASTIE, P. M.; HARESIGN, W. Modulating peripheral gonadotrophin levels affects follicular expression of mRNAs encoding insulin-like growth factor binding proteins in sheep. Animal Reproduction Science, Amsterdam, v. 119, n. 3, p. 198-204, 2010.
HEMAMALINI， N. C.; RAO, B. S.; TAMILMANI, G. ; AMARNATH, D.; VAGDEVI, R. ; NAIDU, K. S. ; REDDY, K. K. ; RAO, V. H. Influence of transforming growth factor- $\alpha$, insulin-like growth factor-II, epidermal growth factor or follicle stimulating hormone on in vitro development of pre antral follicles in sheep. Small Ruminant Research, Amsterdam, v. 50, n. 1-2, p. 11-22, 2003.

IHAKA， R.; GENTLEMAN， R. R: A language for data analysis and graphics. Journal of Computational and Graphical Statistics, Auckland, v. 5, n. 6, p. 299-314, 1996.

LAGARAINE, C.; SKIPORE, J.; SZCZEPKOWSKA, A.; DUFOURNY, L.; THIERY, J. C. Tight junction proteins vary in the choroid plexus of ewes according to photoperiod. Brain Research. Amsterdam. v. 1393, n. 6, p. 44 - 51, 2011.

LETELIER, C. A.; CONTRERAS-SOLIS I.; GARCÍA-FERNÁNDEZC， R. A.; SÁNCHEZ, M. A.; GARCÍA-PALENCIA, P.; SÁNCHEZ, B.; ARIZNAVARRETA, C.; TRESGUERRES, J. A. F.; FLORES, J. M.; GONZALEZ-BULNES, A. Effects of oestrus induction with progestagens or prostaglandina analogues on ovarian and pituitary function in sheep. Animal Reproduction Science, Amsterdam, v. 126, n. 6, p. 61-69, 2011.

LINDNER, L. E. Improvements in the Silver-staining Technique for Nucleolar Organizer Regions (AgNOR). Journal of Histochemistry \& Cytochemistry, Copenhagen, v. 41, n. 3, p. 439-445, 1993.

LÖHR, C. V., TEIFKE, J. P., FAILING, K. WEISS, E. Characterization of the proliferation state in canine mammary tumors by the standardized AgNOR method with postfixation and immunohistologic of Ki-67 and PCNA. Veterinary Pathology Online, Ontário, v. 34, n. 3, p. 212-221, 1997. 
MOAKHAR, H. K.; KOHRAM, H.; SALEHI, R.; SHAHNEH, A. Z. Follicular and ovulatory responses of the right versus left ovaries to eCG treatment in Shall Iranian ewes. African Journal of Biotechnology, Bowie, v. 9, n. 10, p. 1523-1527, 2010.

MURRAY, A. W. Recycling the Cell Cycle: Cyclings Revisited. Cell, Amsterdam, v. 116, p. 221-234, 2004.

PICH, A.; CHIUSA, L.; MARGARIA, E. Prognostic relevance of AgNORS in tumor pathology. Micron, Amsterdam, v. 31, n. 2, p. 133-141, 2000.

PLOTON, D.; MENAGER, M.; JEANNESSON， P.; HIMBER， G.; PIGEON, F.; ADNET, J. J. Improvement in the staining and in the visualization of the argyrophilic proteins of the nuclear organizer regions at the optical level. The Histochemical Journal, Brisbane, v.18, n.1, p. 5-14, 1986.

RIVERA， O. E.; VARAYOUD， J.; RODRÍGUEZ, H. A.; MUNOZ-DETORO, M.; LUQUE, E. H. Neonatal exposure to bisphenol $\mathrm{A}$ or diethylstilbestrol alters the ovarian

follicular dynamics in the lamb. Reproductive Toxicology, Amsterdam, v. 32, n. 3, p. 304-312, 2012.

RODRIGUES, P. A.; COELHO, L. A.; NONAKA, K. O. SASA, A., VICENTE, W. R. R., BALIEIRO, J. C. D. C.; SIQUEIRA, E. R. D. Annual characteristics of estrous activity in wool and hair ewe lambs under subtropical conditions. Scientia Agricola, Piracicaba, v.64, n.5, p.468-475, 2007.

ROSA, H. J. D.; BRYANT, M. J. Seasonality of reproduction in sheep. Small Ruminant Research, Amsterdam, v. 48, n. 3, p. 155-171, 2003.

SANCHES, O. C. Quantificação dos mastócitos nas neoplasias mamárias malignas de cadelas: análise histopatológica, histoquímica e imunoistoquímica. 2010. 83f. Tese (Doutorado em Medicina Veterinária) Faculdade de Medicina Veterinária e Zootecnia, Universidade Estadual Paulista, Botucatu.

SASA, A.; TESTON, D.C.; RODRIGUES, P. A.; COELHO, L. D. A.; SCHALCH, E. Concentrações Plasmáticas de Progesterona em Borregas Lanadas e Deslanadas no Período de Abril a Novembro, no Estado de São Paulo. Revista Brasileira de Zootecnia, Brasília, v. 31, n. 3, p. 1150-1156, 2001.

SILVA, C. M.; SERAKIDES, R.; NASCIMENTO, E. F.; NUNES, V. A., RIBEIRO, A. F.; OCARINO, N. M. Quantificação das regiões organizadoras de nucléolo (NORs) como parâmetro para avaliar a proliferação das células da granulosa. Arquivo Brasileiro de Medicina Veterinária e Zootecnia, Belo Horizonte, v. 55, n .1, p. 113-116, 2003.

SIMPLICIO, A. A.; SALLES, H. O.; SANTOS, D. O. Transferência de embriões nos pequenos ruminantes domésticos. Revista Brasileira de Reprodução Animal, Belo Horizonte, v. Supl, n. 5, p. 17-27, 2002.

SISSON, S. Aparelho Urogenital do Ruminante. In: SISSON, S.; GROSSMAN, J.D. Anatomia dos animais domésticos. 5.ed. Rio de Janeiro: Guanabara Koogan, 1986. v.1. p.879-895.

SOUZA, M. I. L.; URIBE-VELÁSQUEZ, L. F.; OBA, E. SÁ FILHO, O. G.; DE AMORIM RAMOS, A. Secreção de esteróides ovarianos, em ovelhas mestiças de raças exploradas para corte, em distintos momentos reprodutivos, no estado de São Paulo. Ciência Animal Brasileira, Goiania, v. 9, n. 4, p. 1107-1113, 2008.

TASENDE, C.; MEIKLE, A.; RODRÍGUEZ-PIÑÓN, M. FORSBERG, M.; GARÓFALO, E. G. Estrogen and progesterone receptor content in the 
pituitary gland and uterus of progesteroneprimed and gonadotropin releasing hormone-treated anestrous ewes. Theriogenology, Milão, v. 57, n. 6, p.1719-1731, 2002.

TRALDI, A. S. Biotécnicas Aplicadas em Reprodução de Pequenos Ruminantes. In: FEIRA INTERNACIONAL DE CAPRINOS E OVINOS, 3. 2006, Pirassununga. Anais... Pirassununga: [s.n] 2006, p.1-11.

TRERÈ, D. AgNOR staining and quantification. Micron, Amsterdam, v. 31, n. 2, p. 127-131, 2000.

UNDERWOOD, J. C. AgNOR measurements as indices of proliferation, ploidy and prognosis. Clinical molecular pathology, Sydney, v. 48, n. 5, p. 239-240, 1995.

USLU, B. A.; TASAL, I.; GULYUZ, F.; SENDAG, S.; UCAR, O.; GOERICKEPESCH, S. Effects of oestrus synchronisation using melatonin and norgestomet implants followed by eCG injection upon reproductive traits of fattailed Morkaraman ewes during suckling, anoestrus season Wehrend. Small Ruminant Research, Amsterdam, v. 108, n. 1, p. 102-106, 2012.

URIBE-VELASQUEZ, L. F.; OBA, E.; SOUZA, M. I. L. Efeitos da progesterona exógena sobre o desenvolvimento folicular em ovelhas. Arquivo Brasileiro de Medicina Veterinária e Zootecnia, Belo Horizonte, v. 60, n. 1, p. 58-65, 2008.

VILARIÑO, M.; RUBIANES, E.; MENCHACA, A. Ovarian responses and pregnancy rate with previously used intravaginal progesterone releasing devices for fixed-time artificial insemination in sheep. Theriogenology, Milão, v. 79, n. 1, p. 206-210, 2013.

YOUNG, M. J.; MCNEILLY, A. S. Theca: the forgotten cell of the ovarian follicle.
Reproduction, Nottingham v.140, n.4, p.489-504, 2010. 